\section{KONSTRUKSI KOMODIFIKASI MEDIA KOMUNIKASI UNTUK KAMPANYE SOSIAL DI INSTAGRAM DALAM PENCEGAHAN VIRUS CORONA PADA NEW ERA MASYARAKAT 5.0}

\author{
${ }^{1}$ Ilona Vicenovie Oisina Situmeang \\ ${ }^{2}$ Ivonne Ruth Situmeang
}

${ }^{1}$ Pascasarajana Fakultas Ilmu Komunikasi, Universitas Persada Indoensia, Y.A.I. Jakarta

${ }^{2}$ Fakultas Kedokteran Universitas Methodist Indonesia, Medan

Ilonaoisina@yahoo.com

Diterima : 20 Maret 2020; Review : 18 juni 2020; Direvisi Author : 20 juli 2020; Terbit : 14 Agustus 2020

\title{
Abstrak
}

The Corona virus is a virus that is feared by all humans in this world because it is a disease caused by a virus that is deadly to mankind. Until now, there has not been found a vaccine or drug that can deny and cure this virus. Since the corona virus has spread throughout the world, the level of concern of the world community has begun to increase on the importance of maintaining a healthy lifestyle and has begun to play a role in sharing important information in the form of campaigns about Health with friends and the general public. One of the media used to share this is Instagram media, Instagram media is one of the health campaign media that is often used by ministries, private government, communities and individuals in delivering Health campaign messages. The question in this research is how social campaigns are being diagramed in preventing the corona virus in the New Era 5.0 Society. In this study using the diffusion theory of innovation with the concept of persuasive communication, social campaigns, the use of social media for campaign messages and the Corona Virus. Research approach: qualitative. The research paradigm: the post-positivism paradigm. Research type: exploratory. The results show that users of media programs from ministries, governments, communities and individuals design in advance interesting content and videos that will be shared in order to attract people who see them.

Keyword: Health Campaign, Instagram, Covid-19 prevention, New era

\section{PENDAHULUAN}

Corona virus (COVID-19) yang

lebih dikenal dengan nama virus Corona adalah jenis baru dari corona virus yang menular ke manusia. Infeksi virus ini disebut COVID-19 dan pertama kali ditemukan di kota Wuhan, Cina, pada akhir Desember 2019 (Situmeang 2020) ${ }^{1}$
Sudah meluas ke seluruh dunia hingga saat ini 07 September 2020 tercatat total 27.000.000 jiwa sementara yang meninggal mencapai 890.000 jiwa. Corona virus adalah kumpulan virus yang bisa menginfeksi sistem pernapasan. Pada banyak kasus, Virus-Corona ini menyerang saluran pernapasan mulai dari 
yang ringan sampai yang berat. Gejalanya adalah demam, batuk dan sesak nafas, bersifat akut, dan biasanya pasien memiliki penyakit komorbid (penyakit penyerta) dan virus ini juga bisa menyebabkan infeksi pernapasan berat (Situmeang, 2020).

Data Kementerian Kesehatan RI menunjukkan sampai 08 september 2020 Positif terinveksi virus covid 19 sebanyak 200.035 jiwa Sembuh 142.958 jiwa Meninggal 8.230 jiwa dari seluruh Provinsi di Indonesia. Penyakit virus corona dapat diantisipasi dengan menerapkan hidup sehat dengan menjaga pola makan dan pola tidur sehat, sering mencuci tangan dengan sabun atau cairan pembersih tangan mengandung alkohol dan menggunakan masker saat berpergian keluar rumah. Pemerintah Indonesia menghimbau seluruh masyarakat Indonesia untuk menerapkan hidup sehat untuk kesehatan bersama. Kementerian Kesehatan, komunitas bahkan perorangan banyak membuat kampanye Kesehatan untuk saling mengingatkan agar kita dapat hidup berdampingan dengan virus yang mematikan ini. Program-program tersebut biasanya disebarluaskan melalui media sosial untuk menginformasikan kepada masyarakat.

Dalam membuat kampanye Kesehatan membutuhkan strategi untuk mencapai suksesnya program kampanye. Kampanye merupakan tindakan untuk mendapatkan dukungan dengan menggunakan berbagai media komunikasi. Dengan kemajuan teknologi dapat manfaatkan untuk media sosial seperti Instagram untuk berbagi informasi Kesehatan yang terkait dengan Covid - 19. Program kampanye yang banyak ditemukan dimedia Instagram merupakan salah satu bentuk kepedulian kita dengan sesama dalam penyebaran informasi, pengetahuan, gagasan, kesadaran dan ide. Untuk membangun atau menciptakan kesadaran bersama. Kebutuhan akan informasi dapat muncul dalam setiap aspek kehidupan dari tahap yang paling kecil dengan sesama manusia (komunikasi antar pribadi) hingga menjadi kebutuhan untuk menginformasikan program-program kesehatan yang dilakukan pemerintah kepada sesama dengan menggunakan media instagram yang dimiliki.

Kampanye bisa melalui media konvensional maupun media online. Salah satu media online yang banyak ditemui melakukan kampanye Kesehatan adalah melalui media social Instagram Pemanfaatan media social instagram tidak hanya sebagai media hiburan, media jualan dan media branding namun juga dapat digunakan untuk media kampanye yang 
dapat diandalkan untuk tujuan komersil ataupun non komersil. Instagram merupakan salah satu Public Sphere yang ada. Public Sphere atau ruang publik adalah konsep kemerdekaan berpendapat (Situmeang, 2020) ${ }^{2}$.

Media Instagram yang digunakan untuk kampanye Kesehatan tidak hanya diposting oleh kementerian, swasta, komunitas tetapi juga perorangan sebagai media pembelajaran masyarakat untuk mengetahui dan memahami perilaku mana yang diharuskan, diperbolehkan dan dianjurkan dan yang tidak boleh dilakukan. Gerakan hidup sehat untuk memasyarakatkan kebiasaan hidup sehat masyarakat melalui tagline kampanyekampanye yang hingga saat ini terus diterapkan oleh masyarakat Indonesia seperti kampanye \#yukdirumahsaja, lalu kampanye sosial Distancing dan kampanye Physical Distancing. Kampanye kesehatan ini harus diketahui seluruh masyarakat untuk dapat dilakukan secara bersama yang berguna untuk memutuskan rantai penularan Covid-19.

Kesadaran akan mengkampanyekan hidup sehat banyak dilakukan oleh akun perorangan dengan tujuan memberikan edukasi seputar menjaga Kesehatan pada masa pandemic seperti saat ini kepada follower. Salah satunya akun edwardsuhadi dimana dalam setiap postingannya mengajak untuk mengikuti pola hidup sehat. Berbagi kegiatan hidup sehat yang dilakukannya dibagikan melalui postingan, dimana kegiatan yang dilakukan mudah untuk dilaksanakan oleh orang lain, sehingga muncul ketertarikan orang laun untuk mengikutinya.

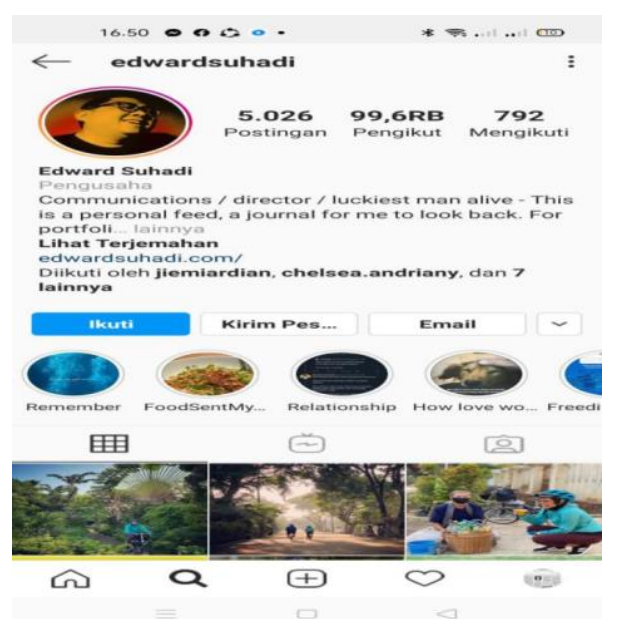

Gambar 1: Akun Edward Suhadi

Selain akun perorangan ada banyak kampanye sosial yang dilakukan oleh komunitas Kesehatan, salah satunya komunitas yang peduli akan Kesehatan di masa pandemic yang selalu berbagi informasi seputar hidup sehat. Follower dapat mengetahui berbagai informasi seputar hidup sehat yang mudah untuk dipraktekkan dalam kehidupan. 


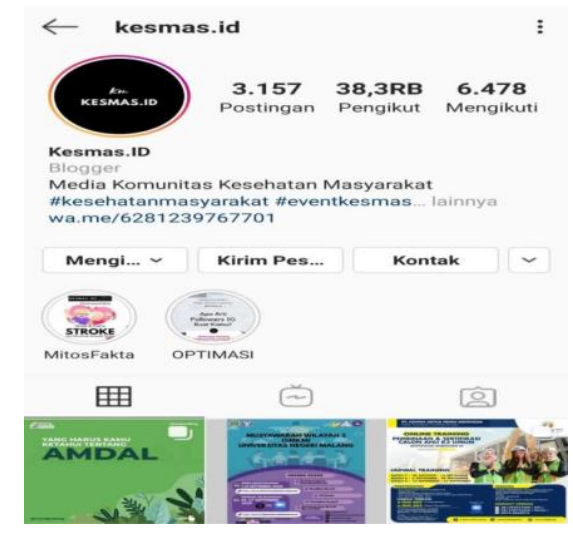

Gambar 2 : Akun divija_id

Kampanye sosial juga banyak dikelola oleh kementerian dan pemerintah dengan menggunakan berbagai media untuk menyebarluaskan informasi yang disajikan biasanya lebih komplit dibandingkan dengan informasi dari perorangan maupun komunitas.

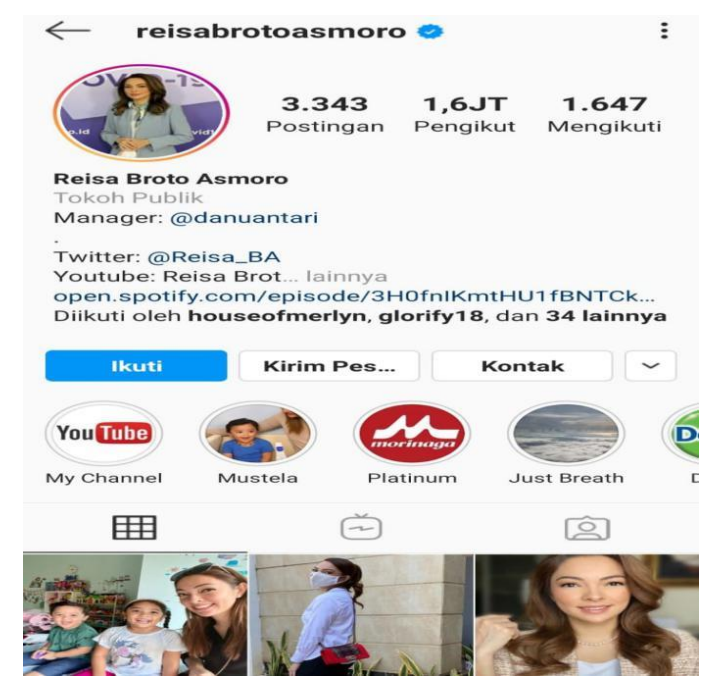

Gambar 3 : akun reisabrotoasmoro

Upaya untuk meningkatkan perilaku hidup sehat diperlukan kampanye Kesehatan yang berkelanjutan, tidak hanya dilakukan satu atau dua kali saja namun terus menerus sehingga mampu untuk mempersuasikan masyarakat. Kampanye kesehatan senantiasa berkaitan dengan sebuah isu yang spesifik seperti saat ini covid 19, sehingga masyarakat dapat mengetahui penyebab, dampak dan solusinya. Namun dalam melakukan kampanye diperlukan proses dalam jangka waktu tertentu untuk dapat berhasil mempengaruhi masyarakat. Itulah sebabnya rencana pembuatan kampanye kesehatan lebih menitikberatkan persoalan taktik dan strategi yang menarik ketimbang isu.

Kampanye dengan taktik dan strategi yang menarik akan mudah dipahami oleh masyarakat. Hanya saja, kampanye kesehatan adalah semacam intervensi sosial terhadap persoalan masyarakat yang pada gilirannya menghasilkan aksi sosial untuk menyelesaikan persoalan tersebut. Keberhasilan kampanye kesehatan akan ditentukan juga oleh perubahan sosial yang terjadi dalam masyarakat. Salah satu perubahan sosial yang sering terlihat 
dalam masyarakat Indonesia akhir-akhir ini adalah respon yang sangat spontan terhadap informasi yang disiarkan dan disampaikan oleh media (Adityawan, 2015) $)^{3}$. Masyarakat begitu mudahnya untuk dapat merespon informasi yang disiarkan dan disampaikan oleh media namun masyarakat juga harus peka terhadap informasi yang menyesatkan (hoax).

Mengkampanyekan kebiasaan hidup sehat dengan berbagi informasi melalui media Instagram dalam kampanye sosial upaya pencegahan virus corona atau Covid-19 dengan menggunakan media Instagram, sehingga dapat mewujudkan dan meningkatkan kesehatan masyarakat secara merata. Kesehatan merupakan hak asasi manusia yang harus dilindungi dan diperhatikan oleh pemerintah. Kesehatan juga merupakan salah satu indikator penting dalam menentukan kesejahteraan suatu bangsa di samping ekonomi dan sosial. Hal ini ditegaskan dalam Undangundang Dasar tahun 1945 pasal 28 ayat 1, yang menyatakan bahwa setiap orang berhak memperoleh pelayanan kesehatan.

Meningkatnya kebutuhan masyarakat akan informasi tentang kesehatan menandai bahwa masyarakat saat ini lebih sadar akan pentingnya menjaga kesehatan supaya terhindar dari
Covid - 19. Kesadaran untuk hidup sehat dan mau berolah raga kini mulai meningkat sejak covid 19 menyebar diseluruh Indonesia. Mulai dari melakukan jalan pagi, berolah raga dengan dengan menggunakan sepeda, melakukan senam kecil dirumahmenjadi trend positif di masyarakat. Maka dari itu kampanye untuk membangun dan mengajak masyarakat untuk hidup sehat. Munculnya kesadaran untuk hidup sehat ini membuat pengaruh yang positif bagi masyarakat lainnya.

Diharapkan dengan banyaknya kampanye hidup sehat di media Instagram ini membuat masyarakat terlihat mulai mengutamakan hidup sehat dengan berbagai pola Kesehatan yang diciptakan masing-masing. Maka dari itu perlu adanya gerakan untuk mengajak masyarakat agar tetap mempertahankan kebiasan positif ini untuk membuat kekebalan bagi tubuh dalam melawan covid 19 agar menyadari pentingnya hidup sehat dan mau meluangkan waktu untuk berolah raga. Dalam penelitian ini ingin mengetahui fungsinya media Instagram sebagai salah satu media sosial Instagram yang dapat menyebarkan dan menerima informasi di new era 5.0 society ini. Media Instagram tidak hanya untuk mengembangkan diri namun juga dapat digunakan sebagai media edukasi 
masyarakat dengan postingan yang actual dan faktual.

Dari penjelasan latar belakang diatas maka peneliti merancang pertanyaan penelitian ini adalah: Bagaimana bentuk dan manfaat kampanye kesehatan di instagram dalam pencegahan virus corona di new era?

Dari penjelasan pertanyaan penelitian diatas maka peneliti menetapkan tujuan dalam penelitian ini adalah: untuk mengetahui dan mendeskripsikan bentuk dan manfaat kampanye kesehatan di instagram dalam pencegahan virus corona di new era society 5.0.

\section{METODOLOGI PENELITIAN}

Teori Difusi Inovasi pada dasarnya menjelaskan proses bagaimana suatu inovasi disampaikan (dikomunikasikan) melalui saluran-saluran tertentu sepanjang waktu kepada sekelompok anggota dari sistem sosial. Hal tersebut sejalan dengan pengertian difusi dari Rogers (1961), yitu "as the process by which an innovation is communicated through certain channels over time among the members of a social system." Lebih jauh dijelaskan bahwa difusi adalah suatu bentuk komunikasi yang bersifat khusus berkaitan dengan penyebaranan pesan-pesan yang

\begin{abstract}
Secara teoritis penulisan ini diharapkan dapat menambah dan mengembangkan kajian ilmu komunikasi khususnya pengetahuan tentang kampanye sosial, media sosial, media Instagram, new era dan era society 5.0.

Penelitian ini diharapkan dapat memberikan kontribusi bagi pemerintah, komunitas Kesehatan dan masyarakat dalam mengkampanye virus COVID-19 sebagai bahan masukan dan evaluasi kampanye yang sudah dilakukan.

Penelitian ini diharapkan menjadi sarana penyampaian informasi bagi masyarakat untuk menambah pengetahuan tentang pola hidup sehat dimasa pandemic.
\end{abstract}

berupa gagasan baru, atau dalam istilah Rogers $(1961)^{4}$ difusi menyangkut "which is the spread of a new idea from its source of invention or creation to its ultimate users or adopters."

Teori ini secara luas digunakan untuk berbagai bidang riset, termasuk inovasi komunikasi yang melibatkan teknologi baru. Menurut Rogers (1961), empat elemen utama teori difusi diwujudkan dalam definisi sederhana, yakni difusi merupakan proses suatu inovasi berupa komunikasi melalui saluran (kanal) dari waktu ke waktu di antara anggota suatu sistem sosial. menguraikan 
proses adopsi teknologi yang kemudian dibahas secara luas termasuk dalam adopsi teknologi digital Internet, dan bagaimana ia telah mengubah cara manusia berkomunikasi dan mengadopsi ide-ide baru.

Rogers (1961), menjelaskan bagaimana ide-ide baru menyebar melalui saluran komunikasi dari waktu ke waktu. Internet telah mengubah sifat difusi dengan mengurangi pentingnya jarak fisik antara manusia. Difusi Internet telah mengubah cara manusia berkomunikasi dan mengadopsi ide-ide baru. Rogers mengatakan bahwa teknologi canggih telah menciptakan sebuah revolusi komunikasi, dan individu, melalui munculnya komputer, telah menjadi peserta aktif (active participants). Karena itu, aspek manusia sama pentingnya dengan teknologi sistem media.

Pemikiran Rogers, dalam proses difusi inovasi terdapat 4 (empat) elemen pokok, yaitu:

1. Inovasi; gagasan, tindakan, atau barang yang dianggap baru oleh seseorang. Dalam hal ini, kebaruan inovasi diukur secara subjektif menurut pandangan individu yang menerimanya. Jika suatu ide dianggap baru oleh seseorang maka ia adalah inovasi untuk orang itu.
Konsep 'baru' dalam ide yang inovatif tidak harus baru sama sekali.

2. Saluran komunikasi; 'alat' untuk menyampaikan pesan-pesan inovasi dari sumber kepada penerima. Dalam memilih saluran komunikasi, sumber paling tidakperlu memperhatikan:

a. Tujuan diadakannya komunikasi.

b. Karakteristik penerima. Jika komunikasi dimaksudkan untuk memperkenalkan suatu inovasi kepada khalayak yang banyak dan tersebar luas, maka saluran komunikasi yang lebih tepat, cepat dan efisien, adalah media massa. Tetapi jika komunikasi dimaksudkan untuk mengubah sikap atau perilaku penerima secara personal, maka saluran komunikasi yang paling tepat adalah saluran interpersonal.

3. Jangka waktu; proses keputusan inovasi, dari mulai seseorang mengetahui sampai memutuskan untuk menerima atau menolaknya, dan pengukuhan terhadap keputusan itu sangat berkaitan dengan dimensi 
waktu. Paling tidak dimensi waktu terlihat dalam:

a. Proses pengambilan

keputusan inovasi.

b. Keinovatifan seseorang: relatif lebih awal atau lebih lambat dalammenerima inovasi

c. Kecepatan pengadopsian inovasi dalam sistem sosial.

4. Sistem sosial; kumpulan unit yang berbeda secara fungsional dan terikat dalam kerjasama untuk memecahkan masalah dalam rangka mencapai tujuan bersama

Lebih lanjut teori yang dikemukakan Rogers memiliki relevansi dan argumen yang cukup signifikan dalam proses pengambilan keputusan inovasi. Teori tersebut antara lain menggambarkan tentang variabel yang berpengaruh terhadap tingkat adopsi suatu inovasi serta tahapan dari proses pengambilan keputusan inovasi. Variabel yang berpengaruh terhadap tahapan difusi inovasi tersebut mencakup: (1) atribut inovasi (perceived atrribute of innovasion), (2) jenis keputusan inovasi (type of innovation decisions), (3) saluran komunikasi (communication channels), (4) kondisi sistem sosial (nature of social system), dan (5) peran agen perubah (change agents).

Sementara itu tahapan dari proses pengambilan keputusan inovasi mencakup:

1. Tahap Munculnya Pengetahuan (Knowledge) ketika seorang individu (atau unit pengambil keputusan lainnya) diarahkan untuk memahami eksistensi dan keuntungan/manfaat dan bagaimana suatu inovasi berfungsi

2. Tahap Persuasi (Persuasion) ketika seorang individu (atau unit pengambil keputusan lainnya) membentuk sikap baik atau tidak baik

3. Tahap Keputusan (Decisions) muncul ketika seorang individu atau unit pengambil keputusan lainnya terlibat dalam aktivitas yang mengarah pada pemilihan adopsi atau penolakan sebuah inovasi.

4. Tahapan Implementasi (Implementation), ketika sorang individu atau unit pengambil keputusan lainnya menetapkan penggunaan suatu inovasi.

5. Tahapan Konfirmasi (Confirmation), ketika seorang individu atau unit pengambil keputusan lainnya mencari penguatan terhadap 
keputusan penerimaan atau penolakan inovasi yang sudah dibuat sebelumnya.

Dalam komunikasi persuasif diharapkan orang yang menerima pesan dapat berubah sesuai dengan pesan yang disampaikan. Komunikasi persuasif bentuk komunikasi yang memiliki tujuan untuk mempengaruhi perilaku manusia. Menurut Heryanto $(2018)^{5}$ komunikasi persuasif merupakan proses simbolik di mana komunikator mencoba meyakinkan orang lain untuk mengubah sikap atau perilaku mereka. Pemilih menerima pesan persuasi dalam kesukarelaan untuk menerima, menolak atau pun tak berkomitmen apapun.

Menurut Liliweri $(2008)^{6}$ tujuan adanya melakukan komunikasi persuasif diantaranya:

a. Perubahan sikap (attitude change), komunikasi persuasif ini diharapkan dapat mengubah pola pikir yang mana pola pikir ini membuat komunikan mengubah sikapnya terhadap pesan apa yang diterimanya.

b. Perubahan pendapat (opinion change), seorang komunikan pastinya memiliki pendapat atau anggapan yang berbeda dari seorang komunikator. Sehingga, perlu adanya komunikasi persuasif ini sebagai alat mengubahnya pola pikir komunikan yang membuat komunikan ini mengikuti pendapat atau anggapan yang disampaikan oleh seorang komunikator.

c. Perubahan perilaku (behavior change), perubahan sikap ini sebenarnya masuk ke dalam kategori perubahan sikap. Namun, perilaku ini merupakan suatu dampak dari sikap. Ketika sikap berubah, maka perilaku pada seseorang atau komunikan pun juga ikut berubah mengikuti pola pikir dari pesan yang ia terima.

d. Perubahan sosial (sosial change). Perubahan sosial inilah yang merupakan salah satu dampak dari adanya bahasa yang persuasif. Komunikator yang berbahasa persuasif akan membawa perubahan dalam lingkungan masyarakat, pola pikir, hingga perilaku masayarakat.

Menurut Ann Gregory (2010) kampanye didefinisikan sebagai suatu tindakan yang bertujuan untuk mendapatkan pencapaian dukungan yang menggunakan berbagai media komunikasi 
untuk mendapatkan dukungan publik. Dalam arti lebih umum atau lebih luas, kampanye tersebut memberikan penerangan secara terus menerus serta pengertian dan motivasi terhadap suatu kegiatan atau program tertentu melalui proses dan teknik komunikasi yang berkesinambungan dan terencana untuk mencapai publisitas dan citra yang positif. Menurut Ruslan (2013) ${ }^{7}$ Pengertian secara umum tentang istilah kampanye yang dikenal sejak 1940-an campaign is generally exemply persuasion in action (kampenye secara umum adalah menampilkan suatu kegiatan dimana bertitik tolak untuk membujuk), dan sudah banyak dikemukakan beberapa ilmuan, ahli dan praktisi komunikasi.

Menurut Venus (2012) ${ }^{8}$ Secara garis besar kampanye memiliki fungsi sebagai penyalur informasi bagi masyarakat, terdapat empatfungsi kampanye, yaitu sebagai berikut:

a. Sebagai sarana yang dapat merubah pola pikir masyarakat.

b. Menggugah kesadaran dan pendapat masyarakat terhadap suatu permasalahan tertentu.

c. Mengembangkan usaha dan membujuk khalayak untuk membeli produk yang dipasarkan

d. Membangun sebuah citra positif di masyarakat.

Menurut Mcquail (Venus, 2012), ada beberapa jenis perubahan yang dapat terjadi karena penggunaan media, yaitu:

a. Dapat menyebabkan perubahan yang diinginkan atau tidak diinginkan.

b. Dapat menciptakan perubahan kecil.

c. Dapat memperlancar atau menghambat perubahan.

d. Dapat memperkuat apa yang sudah ada.

Pemanfaatan media sosial dalam kampanye Ismail (2012) menyatakan konsep Online Social Movement merupakan gerakan sosial dilakukan dengan mengadopsi teknologi internet. Walaupun disebut dengan kata kunci 'online' sebagai Online Social Movement, gerakan ini tidak hanya dilakukan di ruang internet, tetapi konteks offline, atau ruang real juga merupakan bagian penting dari Online Social Movements agar memberikan konteks, validasi dan keterikatan partisipasi dalam melakukan gerakan sosial. Online Social Movement merupakan pilihan masyarakat kontemporer saat ini dalam melakukan aktivisime. Masyarakat sipil telah memainkan peran penting sebagai masyarakat dalam mengisi dan melakukan 
gerakan sosial, mengkritisi pemerintah dengan mengadopsi sosial media yaitu internet.

$\begin{array}{ccrr} & \text { Keterlibatan masyarakat } & \text { sipil } \\ \text { dalam gerakan sosial di internet }\end{array}$ merupakan cara tersendiri dalam berkontribusi untuk membangun dan mengontrol negeri ini. Beberapa jurnal mengenai pemanfaatan media sosial, terutama pada kampanye-kampanye, hasilnya menunjukkan bahwa jenis media sosial yang digunakan diantaranya adalah Facebook, Twitter, LINE, dan Website tetapi yang lebih banyak digunakan dalam pemasaran adalah Facebook dan Twitter. Penggunaan media sosial sebagian besar dimanfaatkan organisasi yang menjalankan kegiatan gerakan sosial, tiga diantaranya merupakan gerakan sosial lingkungan. Tidak hanya untuk gerakan sosial, media sosial pun digunakan dalam mempromosikan olahan pertanian. Media sosial dapat menjadi media komunikasi lingkungan produk, jasa maupun aksi sosial (Ulfa1 dan Fatchiya, 2019) ${ }^{9}$.

Secara sederhana Society 5.0 adalah evolusi perkembangan kehidupan sosial ekonomi manusia.

Society 1.0 adalah saat manusia masih pada fase berburu dimana manusia hidup berdampingan dengan alam.
Society 2.0 disebut adalah masa saat manusia pada fase mulai bertani yang diperkirakan berlangsung sejak 13.000 sebelum masehi. Di masa ini masyarakat telah mengenal sistem irigasi sebagai bagian dari masyarakat agraria. Society 3.0 disebut saat fase masyarakat industri yang lahir pada akhir abad ke 18. Cirinya adalah masyarakat masa itu telah mengenal sistem produksi massal dan juga ditemukannya kereta uap. Society 4.0 disebut saat manusia masuk ke masyarakat informasi yang diperkirakan pada pertengahan abad ke 20. Di masa ini manusia telah mengenal komputer dan menemukan saluran informasi secara masif. Society 5.0 adalah fase saat manusia memasuki era super smart society.

Virus Corona (COVID-19) baru dikenali pertama kali pada tahun 2012 di Negara Arab Saudi. Komite Internasional Taxonomy Virus pada tanggal 28 mei 2013 sepakat menyebut virus corona tersebut dengan nama Middle East Respiratory Syndrome Corona Virus (MERS-CoV) baik dalam komunikasi publik maupun komunikasi ilmiah. Virus Corona merupakan keluarga besar dari virus yang dapat menimbulkan kesakitan maupun kematian pada manusia dan hewan. Penyakit menular MERS-CoV muncul kembali karena belum ada suatu 
cara kontrol yang tepat terhadap penyakit ini, bahkan sampai saat ini juga belum tersedia vaksin untuk penyakit menular tersebut.

MERS-Cov adalah suatu strain baru virus Corona yang belum pernah ditemukan menginfeksi manusia sebelumnya. Virus Corona merupakan keluarga besar dari virus yang dapat menimbulkan kesakitan maupun kematian pada manusia dan hewan. Penyakit menular MERS- CoV muncul kembali karena belum ada suatu cara kontrol yang tepat terhadap penyakit ini, bahkan sampai saat ini juga belum tersedia vaksin untuk penyakit menular tersebut Klasifikasi kasus MERS-Cov adalah Seseorang dengan infeksi saluran pernapasan akut (ISPA) dengan tiga keadaan di bawah ini:

a. Demam $\left(>38^{\circ} \mathrm{C}\right)$ atau ada riwayat demam

b. Batuk

c. Pneumonia berdasarkan gejala klinis atau gambaran radiologis yang membutuhkan perawatan di rumah sakit.

Perlu waspada pada pasien dengan gangguan sistem kekebalan tubuh (immuno-compromised) karena gejala dan tanda tidak jelas.

Pendekatan penelitian: kualitatif. Paradigma penelitian: paradigma post- positivisme. Tipe penelitian: eksploratif. Teknik yang digunakan untuk mengumpulkan data diperoleh dari:

Data Primer, Yang menjadi data primer melalui Wawancara Mendalam Observasi dan Focus Group Discussion. Data Sekunder, Data sekunder diperoleh melalui studi dokumentasi dan studi literatur. Menurut Bodgan dan Biklen, Analisis data kualitatif merupakan upaya yang dilakukan dengan jalan bekerja dengan data, mengorganisasikan data, memilah menjadi satuan yang dapat dikelola, mensintesiskannya, mencari dan menemukan pola, menemukan apa yang penting dan apa yang dipelajari, serta memutuskan apa yang dapat diceritakan kepada orang lain. (Moleong 2013) 9 .

Dalam penelitian ini yang diwawancarai adalah Friska Pardosi yang peduli tentang Kesehatan terutama dimasa pandemic dan Ende Putri Renata yang peduli melakukan kampanye Kesehatan dilingkungan masyarakat dan keluarga. Teknik menentukan informan dengan non probability sampling yaitu memakai kriteria tertentu diantaranya: Pernah melakukan kampanye Kesehatan di masa pandemic dan memiliki media Instagram sebagai media untuk berbagi informasi Kesehatan. Miles and Huberman (Sugiyono, 2013) ${ }^{10}$ yang menyatakan 
bahwa aktivitas dalam analisis data kualitatif dilakukan secara interaktif dan berlangsung secara terus-menerus sampai tuntas, sehingga datanya sudah jenuh.

\section{HASIL DAN PEMBAHASAN}

Situasi saat ini penyebaran Covid-19 masih merupakan penyakit yang sangat ditakutkan oleh seluruh masyarakat dunia, hal ini dikarenakan belum ada vaksin dan obat yang bisa menyembuhkan penyakit didalam tubuh manusia. Penyakit Covid19 ini merupakan penyakit yang paling banyak memakan korban diseluruh dunia. Berbagai macam cara sudah dilakukan dunia namun belum membuahkan hasil yang maksimal. Bahkan negara-negara maju dan terdepan dibidang Kesehatan juga mengalami hal yang sama dengan adanya Covid-19 ini. Rasa kemanusiaan yang tinggi terlihat dari berbagai macam upaya yang dilakukan oleh setiap orang untuk berbagi informasi seputar Covid-19.

Menggunakan media sosial untuk melakukan kampanye Kesehatan dan saling berbagai informasi kepada pihak lain. Kampanye sosial terkait dengan pencegahan Covid-19 bermuncullan dengan berbagai macam tujuan positif yang ingin didapatkan. Sama halnya kampanye yang dilakukan melalui media Instagram, dengan berbagai bentuk pesan
Aktivitas meliputi reduksi data (data reduction), penyajian data (data display) dan penarikan kesimpulan (verification).

yang dirancang semenarik mungkin agar pihak lain tertarik untuk membaca dan memahami pesan-pesan Kesehatan yang disampaikan. Menjaga kesehatan mental dan kesehatan tubuh merupakan salah satu cara alami untuk menjaga kondisi tubuh tetap prima. Pada keadaan seperti sekarang ini tubuh prima sangat dibutuhkan untuk menyangkal virus Covid - 19 yang menyerang tubuh manusia.

Karena vaksin dan obat belum ditemukan sampai saat ini, setiap orang tergerak untuk melakukan kampanye sosial melalui media instagram untuk saling mengedukasi dalam penyebaran pesan berupa ide, gagasan dan inovasi kepada sejumlah besar orang. Bagaimana suatu ide, gagasan, atau inovasi yang ada pada kampanye sosial tersebut dapat diperkenalkan, dijelaskan kepada semua orang hingga menimbulkan efek positif bagi masyarakat dan memiliki kebermanfaatan.

Kampanye kesehatan merupakan salah satu cara yang dapat dilakukan untuk membuat perubahan pada diri individu dan 
masyarakat. Saling berbagi informasi melalui media sosial untuk memberikan informasi untuk hidup sehat yang tetap dilakukan pada masa pandemic, dengan cara menggunakan masker jika berpergian, sering mencuci tangan terutama pada saat memegang bagian muka dan saat sebelum makan, mengkonsumsi makanan dan minuman yang sehat, menghindari mengkonsumsi minuman beralkohol dan rokok, menjaga jarak aman pada saat melakukan komunikasi dengan lawan bicara.

Melalui kampanye Kesehatan yang banyak dilakukan melalui media Instagram diharapkan memberikan kesadaran bagi masyarakat. Pada umumnya kampanye sosial dilakukan selalu menggunakan berbagai media sebagai saluran pengirim pesan kepada masyarakat, media internet merupakan salah satu media yang digunakan hampir seluruh masyarakat dunia. Perkembangan teknologi Society 5.0 memungkinan kita untuk menggunakan ilmu pengetahuan yang berbasis modern dalam melayani berbagai kebutuhan manusia, mewujudkan masyarakat yang menikmati hidup merasa nyaman. Society 5.0 menggunakan teknologi modern hanya saja mengandalkan manusia sebagai komponen utamanya dalam membuat suatu perubahan.

Jika dikaitkan dengan penelitian ini kampanye sosial yang dilakukan oleh banyak pihak baik pemerintah, komunitas maupun perorangan menunjukkan bahwa teknologi modern yang digunakan mengandalkan manusianya dalam melakukan suatu perubahan. Seperti yang terlihat dalam berbagai aktifitas yang diperlihatkan dalam setiap postingan bahwa bukan media sebagai perubah tetapi orangnya yang melakukan komponen perubahan, media sebatas sebagai sarananya. Dengan menunjukkan bahwa setiap perubahan dapat dilakukan oleh manusia jika memiliki kemauan untuk mengalami perubahan.

Jika dikaitkan dengan teori difusi inovasi maka suatu perubahan yang baru disebarluaskan melalui berbagai media komunikasi secara berkesinambungan agar masyarakat menjadi sadar untuk informasi tersebut, namun sebuah perubahan biasanya tidak langsung mudah untuk diadopsi oleh orang lain namun ada proses dan tahapan yang harus dilakukan. Hal ini diperkuat oleh
Menurut Friska Pardosi mengatakan bahwa: mengadopsi sesuatu yang baru selalu melewati proses yang panjang dan waktu 
yang lama agar sesuatu yang baru tersebut dapat diterima ataupun ditolak seseorang. Begitu juga dengan new era di masa pandemic ini, pola hidup sehat yang merupakan sesuatu yang positif saja tidak langsung bisa diadopsi oleh pihak luar karena harus merubah kebiasaan yang ada pada diri seseorang. Beda halnya jika pengadopsian tersebut dipaksa untuk dilakukan kemungkinan besar orang akan "terpaksa" untuk melakukan perubahan.

Dari pendapat diatas menunjukkan bahwa kampanye Kesehatan yang sering dilakukan melalui berbagai media konvensional dan media online membutuhkan waktu Panjang untuk dapat mempersuasikan banyak orang dan kegiatan kampanye harus dilakukan secara berkesinambungan agar tujuan untuk mempersuasikan orang dapat berjalan dsesuai dengan tujuan yang diharapkan. Era Society 5.0 ini merupakan era dimana teknologi adalah bagian dari manusia itu sendiri. Media internet bukan hanya media berbagai informasi tentang bahayanya Covid 19, pencegahan dan pengobatan namun untuk menjalani kehidupan seseorang agar informasi tersebut dapat diterima.
Tujuan kampanye sosial yang dilakukan harus terus dilakukan untuk mencapai perubahan tertentu, seperti perubahan sikap dan perilaku dari sejumlah besar individu yang akan dijadikan sasaran kampanye. Perubahan sikap dan perilaku individu itu merupakan outcomes dari kampanye sosial yang dilakukan selama ini dengan menggunakan media apapun. Kampanye sosial merupakan salah satu metode komunikasi persuasif dalam melakukan penyebaran pesan kepada masyarakat sehingga pesanpesan itu diharapkan dapat lebih cepat menjangkau masyarakat.

Adopsi dalam kampanye sosial tentang kesehatan pada hakekatnya dapat diartikan sebagai proses penerima inovasi atau perubahan perilaku yang baik berupa pengetahuan (Cognitive), sikap (affective), maupun perilaku (psychomotoric) pada diri sesorang setelah menerima "inovasi" yang disampaikan melalui media. Adopsi berarti menerima sesuatu yang "baru" yang ditawarkan dan diupayakan oleh pihak lain demi tercapainya tujuan tertentu.

Penilaian tingkat adopsi inovasi bisa dilakukan dengan menggunakan tolok ukur seberapa banyak masyarakat memahami pesan kampanye yang disampaikan melalui media Instagram. 
Tergantung pada proses perubahan perilaku, proses pencapaian tahapan adopsi dapat berlangsung secara cepat maupun lambat. Dari perubahan perilaku yang terjadi, adopsi yang berlangsung melalui proses yang perlahan hingga melalui pemaksaan. Proses perlahan dapat terlihat dengan banyaknya kampanye Kesehatan diberbagai media setiap orang yang merasa butuh akan menerima pesannya dan mengadopsinya namun sebaliknya yang merasa tidak membutuhkan akan mengabaikan.

Namun jika dilakukan dengan cara pemaksaan agar setiap orang mengadopsi terlihat dengan adanya Tindakan langsung yang dilakukan pemerintah jika tidak mematuhi protocol Kesehatan. Namun jika perubahan dengan cara pemaksaan biasanya lebih cepat berubah kembali, segera setelah unsur kegiatan pemaksaan tersebut tidak dilanjutkan lagi. Hal ini terlihat dengan terus meningkatnya jumlah masyarakat yang tertular Covid-19 sejak dilonggarkan Pembatasan Sosial Berskala Besar masyarakat sudah tidak mematuhui protokol Kesehatan lagi, berbeda dengan masyarakat yang mendapatkan informasi secara perlahan melalui berbagai info Kesehatan sehingga masyarakat yang mendapatkan informasi secara perlahan melalui instagraakan bertahan lama dalam mengadopsi perubahan baru mengenai Kesehatan selama masa pandemic.

Kekuatan instagram

dalam mempengaruhi masyarakat melalui penyampaian pesan-pesan persuasive dengan berbagai bentuk, ada yang berbentuk poster maupun video yang dapat dilihat oleh banyak orang. Berkembangnya teknologi diera society 5.0. Konten merupakan sesuatu yang utama yang harus diperhatikan bagi siperancang kampanye. Dimana konten yang menarik dan bervariasi dapat membuat daya Tarik tersendiri bagi yang melihatnya. Konten tidak monoton hanya pada informasi yang berulang namun dibuat dengan berbagai bentuk yang menarik dan berbeda.

Menurut Ende mengatakan bahwa: bagaimana merancang konten kampanye agar dapat dipahami sebagai metode dan teknik yang terbaik bagi aktivitas pengiriman dan pertukaran informasi yang bertujuan untuk membujuk dan memobilisasi khalayak agar tertarik untuk melihat kampanye Kesehatan tersebut. Kampanye Kesehatan yang dirancang dapat diarahkan untuk memenuhi beberapa tujuan misalnya menciptakan dialog dan diskusi, melakukan lobi, membujuk 
masyarakat tentang mengubah sikap dan perilaku hidup sehat yang dapat memberikan manfaat bagi banyak orang.

Melalui kampanye Kesehatan ini penyampai pesan memiliki keinginan untuk dapat berhasil mempengaruhi khalayak, menimbulkan kepercayaan, merubah tingkah laku, menimbulkan minat serta keinginan khalayak untuk dapat hidup sehat agar terhindar dari penularan Covid-19. Daya tarik konten diperlukan dalam mengkampanyekan pola hidup sehat dengan menggunakan interaksi simbolik melakukan pengoperan simbol-simbol atau lambang komunikasi yang mempunyai makna tertentu dalam berkampanye. Lambang komunikasi bisa berbentuk bahasa, baik tulisan maupun lisan, tanda (sign), gambar-gambar, isyarat yang telah dirumuskan sedemikian rupa sehingga dapat menarik perhatian sekaligus berpengaruh terhadap pesan kesahatan yang disampaikan. Pada akhirnya akan menimbulkan efek yang sesuai dengan tujuan kampanye kesehatan yang telah direncanakan oleh komunikator.

Dengan konten yang menarik komunikan termotivasi untuk melakukan sesuatu dengan senang hati apa sesuai dengan yang diharapkan oleh komunikator. Pesan kampanye merupakan bentuk pesan yang berisikan imbauan, motivasi, dan persuasi untuk hidup sehat selama pandemic sehingga kebiasan hidup sehat ini diadopsi oleh masyarakat dan akan terus berkelanjutan dalam meningkatkan kesadaran dan pengetahuan khalayak. Untuk dapat merebut perhatian serta menumbuhkan persepsi atau opini yang positif dari pesan yang disampaiakan pesan disampaikan secara intensif dan jangka waktu tertentu yang berkelanjutan. Memberikan informasi dan penerangan secara terus-menerus dan memberikan respon bagi setiap pertanyaan yang mungkin saja muncul sehingga khalayak mendapatkan pengetahuan baru tentang pola hidup sehat.

Menurut Friska mengatakan bahwa metode kampaye yang dapat dilakukan baik melalui pemerintah, kementerian, komunitas maupun perorangan harus tetap dilakukan secara berencana, sistematis, memotivasi, psikologis dan dilakukan berulangulang serta kontinu. Sebaliknya, kampanye kesehatan tersebut dilakukan tidak hanya sekali namun berulang-ulang untuk menumbuhkan rasa kebiasaan dimasyarakat, agar pengadopsian 
hal yang baru tidak mudah dilupakan atau ditinggalkan.

Bentuk-bentuk kampanye yang dilakukan kementerian, komunitas maupun perorangan yang terkait dengan kampanye Kesehatan dimasa pandemic ini dibuat dengan berbagai versi.seperti yang ada pada gambar dibawah ini:

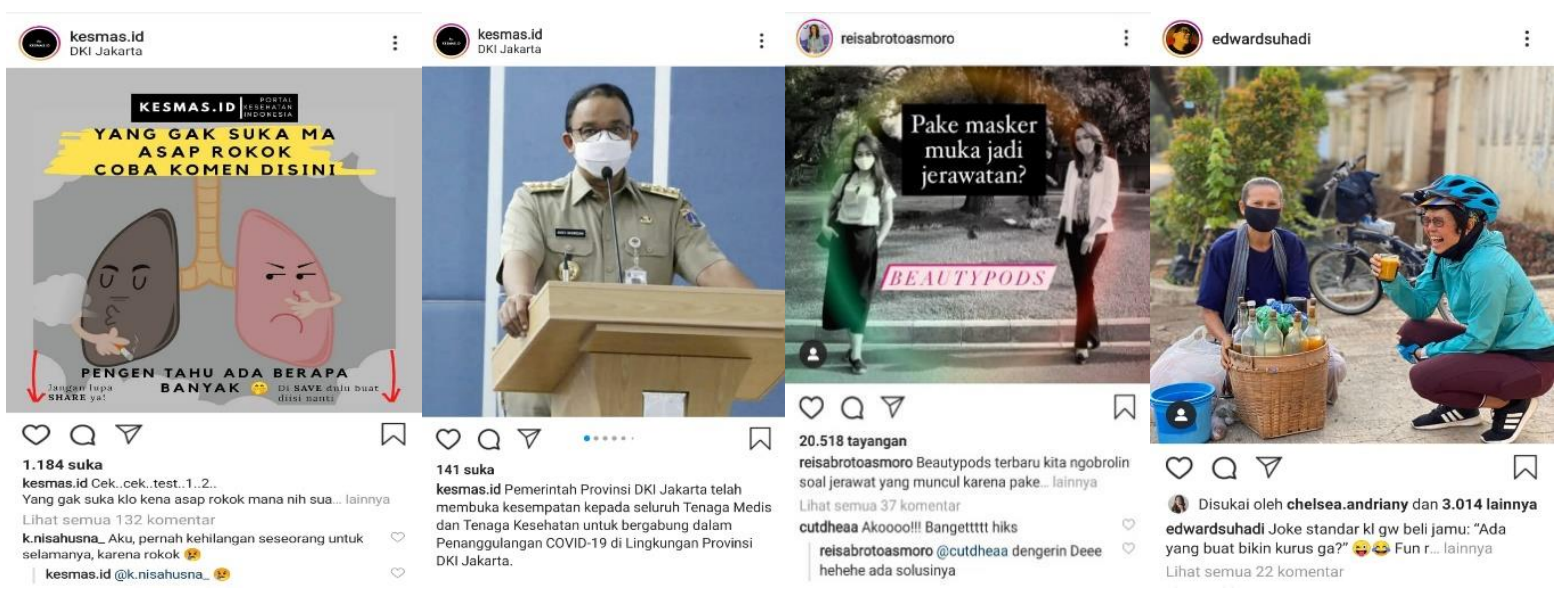

Gambar 4 : Konten Kampanye di Instagram

Ada yang dibuat dengan Bahasa yang santai dengan visual yang menarik, ada konten yang dibuat dengan menyertakan pemerintah untuk memberikan unsur formal dalam kampanye yang sedang berlangsung. Ada konten menunjukkan poto asli dari yang sedang melakukan aktifitas Kesehatan. Hal-hal yang seperti ini yang harus diperhatikan agar kampanye melalui media Instagram. Kampanye yang sering dilakukan adalah Ideologically or caused oriented campaigns adalah jenis kampaye yang berorientasi pada tujuan-tujuan yang bersifat khusus dan seringkali berdimensi perubahan sosial. Dalam hal ini kampanye yang khusus membahas tentang Kesehatan dan diharapkan dampaknya akan bisa melakukan perubahan sosial. Karena itu kampanye jenis ini sering disebut sebagai social change campaigns, yakni kampanye yang ditujukan untuk menangani masalahmasalah sosial melalui perubahan sikap dan perilaku publik.

Pola hidup sehat saat menjadi sesuatu yang wajib dipenuhi untuk menuntaskan penyebaran Covid-19 ini. Semakin banyak pemerintah, swasta, komunitas Kesehatan dan perorangan dengan sadar membuat membantu menyebarkan informasi tentang pola hidup sehat melalui berbagai media. Berbicara tentang kampanye, pemerintah Indonesia akhir-akhir ini sedang gencar-gencarnya 
melakukan kegiatan kampanye terkait penyebaran Virus Corona di Indonesia, seperti yang kita ketahui bahwa pada akhir 2019 lalu, dunia digegerkan dengan munculnya wabah penyakit yang terbilang baru, yaitu virus corona yang menyebabkan penyakit Covid-19. Virus yang berasal dari Wuhan tersebut cukup menggegerkan dunia terlebih lagi penyebaran virus ini bukan hanya menular pada warga di Negara Cina saja akan tetapi juga dapat menular hampir ke seluruh Negara di dunia karena cara penyebaran yang cukup rentan yaitu melalui interaksi secara langsung dengan jarak dekat.

\section{PENUTUP}

Penggunanaan media Instagram saat ini sebagai media kampanye kesehatan yang berfungsi untuk menyebarluaskan konten berupa poster dan video seputar kesehatan yang dapat dilihat oleh khalayak untuk menambah informasi cara-cara hidup sehat, pola makan sehat yang berfungsi dalam mencegah Covid-19.

Penggunaan media Instagram sebagai media kampanye Kesehatan tidak hanya akun dari pemerintah dan kementerian saja namun juga akun yang berasal dari komunitas Kesehatan dan perorang sangat banyak dipakai untuk menyebarluaskan informasi Kesehatan dalam menghadapi masa pandemic seperti ini.
Kegiatan kampanye sosial dibidang Kesehatan yang membahas tentang pola hidup sehat, pola makan sehat sangat dibituhkan oleh semua masyarakat saat ini, namun yang diharapkan dalam penyampaian pesan diharapkan semua pihak dapat menyampaikan informasi yang actual dan factual jangan menyampaikan informasi yang tidak bisa dipertanggungjawabkan sehingga setiap pesan Kesehatan yang disampaikan dapat bermanfaat bagi khalayak yang melihat kampanye tersebut.

Diharapkan dalam menggunakan Instagram sebagai media kampanye harus membuat konten yang menarik sehingga dengan konten yang menarik dan beragam akan menimbulkan daya Tarik khalayak dan tidak menimbulkan rasa bosan untuk melihat dan menontonnya.

Rasa kepedulian yang tinggi membuat setiap akun ingin membuat kampanye Kesehatan yang dapat bermanfaat bagi banyak orang, namun yang perlu disadari Bersama bahwa dalam membuat konten harus bisa dipertanggungjawabkan dan bukan berita bohong yang dapat menyesatkan khalayak. 


\section{DAFTAR PUSTAKA}

Gregory, Anne. (2010). Planning and Managing Public Relations Campaigns: A Strategic Approach (PR In Practice). United Kingdom: Kogan Page.

Heryanto, Gun Gun. (2018). Media Komunikasi Politik Relasi Kuasa Media di Panggung Politik. Yogyakarta: Diva Press IRCiSoD.

Moleong, Lexy J. (2013). Metode Penelitian Kualitatif. Edisi Revisi. Bandung : PT. Remaja Rosdakarya.

Rogers, Everett (1983). Difussion of Innovations, London : Coller Macmillan Publisher.

Ruslan, Rosady. (2007). Kampanye

Public Relations. Jakarta:

Raja Grafindo. Persada.

Sugiyono. (2013). Metode Penelitian

Kuantitatif Kualitatif Dan

$R \& D$. Bandung: Alfabeta.

Situmeang. Ilona Vicenovie Oisina. (2020). Menyoal Pro Dan Kontra Penanganan Korona. http://m.kontan.co.id/news/m enyoal-pro-dan-kontrapenanganan-korona 24 Maret 2020.

Situmeang . Ilona Vicenovie Oisina. (2020).Terpaan Postingan Kesehatan Mental Masa Pandemi Covid 19 Dan Kredibilitas Sumber Terhadap Perubahan Sikap (Survey Pada Follower @ Jiemiardian Di Instagram). Pusaran Komunikasi Di
Tengah Badai Covid-19.

Deepublish : Sleman. Ulfa, Ghina Shabrina dan Fatchiya

Anmna. (2019).

EFEKTIVITAS

INSTAGRAM "EARTH HOUR BOGOR" SEBAGAI

MEDIA KAMPANYE

LINGKUNGAN

Effectiveness of Instagram

"Earth Hour Bogor" as a

Environmental Campaign

Media. Jurnal Komunikasi

Pembangunan eISSN 2442-

4102 Bulan Februari, Volume 16, No. 1144

Visualisasi Kampanye Kesehatan Remaja Dalam Media Cetak

Oki Adityawan Universitas

BSI Bandung. Jurnal Sketsa, Vol.II No.1 April 2015

Venus, Antar. (2004). Manajemen

Kampanye: Panduan Teoritis dan Praktis Mengefektifkan

Kampanye Komunikasi.

Bandung: Simbiosa Rekata Media.

https://www.aktualita.co/2019/01/meng enal-apa-itu-society-50.html terhubung berkalau 16 Agustus 2020 Pukul 20:15 WIB 